\title{
LITTLE DRAGONS PREFER FLOWERS TO MAIDENS: A LIZARD THAT LAPS NECTAR AND POLLINATES TREES
}

\author{
Ivan Sazima*, Cristina Sazima*,**, Marlies Sazima***
}

Biota Neotropica v5(n1) - http://www.biotaneotropica.org.br/v5n1/pt/abstract?short-communication+BN00805012005

Recebido: 12/09/2004

Revisado: $12 / 11 / 2004$

Publicado: 01/01/2005

\begin{abstract}
*Departamento de Zoologia e Museu de História Natural, Caixa Postal 6109, Universidade Estadual de Campinas, $13083-970$
Campinas, São Paulo, Brazil (www.unicamp.br)

Corresponding author. Tel: +55-19-3788 7292; fax: +55-19-32893124; e-mail: isazima@unicamp.br

***Departamento de Zoologia, Caixa Postal 199, Universidade Estadual Paulista, 13506-900 Rio Claro, São Paulo, Brazil

***Departamento de Botânica, Caixa Postal 6109, Universidade Estadual de Campinas, 13083-970 Campinas, São Paulo, Brazil
\end{abstract}

\begin{abstract}
Lizards rarely visit and pollinate flowers, the few recent records being mostly restricted to island habitats. We report here on the Noronha skink (Euprepis atlanticus) seeking nectar in the flowers of the leguminous mulungu tree (Erythrina velutina) at Fernando de Noronha Archipelago, off northeast Brazil. The mulungu tree blooms during the dry season, and each flower secretes copious and diluted nectar throughout the day. The Noronha skink climbs up to the inflorescences and laps the nectar accumulated in the flowers' base. While exploiting the flowers and crawling over the inflorescences, the body parts of the skink contact the anthers and stigmas and pollen adheres to the lizard's scales. The lizard visits inflorescences from the same and different trees, which renders it a potential pollinator. As the mulungu tree blooms during the dry season and the island has little or no natural freshwater supply during drought periods, we suggest that the Noronha skink seeks flower nectar both for its energetic, diluted sugars and the water content.
\end{abstract}

Key words: Euprepis atlanticus, Scincidae, Erythrina velutina, Fabaceae, saurophily, oceanic islands.

\section{Resumo}

Lagartos raramente visitam e polinizam flores, os poucos registros estando restritos a ambientes insulares. Registramos aqui a mabuia de Noronha (Euprepis atlanticus) buscando néctar nas flores da árvore leguminosa mulungu (Erythrina velutina), no Arquipélago de Fernando de Noronha ao largo da costa Nordeste do Brasil. O mulungu floresce na época seca, ao longo de quatro meses. As flores produzem néctar muito diluído e abundante, ao longo do dia todo. A mabuia percorre as inflorescências, lambendo o néctar acumulado na base da flor. Enquanto rasteja sobre as inflorescências da mesma ou outra árvore, contata as anteras e os estigmas e o pólen fica aderido ao seu corpo, o que torna a mabuia um polinizador potencial. Como o mulungu floresce durante a época seca, período em que a água é muito escassa na ilha, sugerimos que a mabuia visita as flores tanto pelos açúcares diluídos e energéticos, como pela água contida no néctar.

Palavras-chave: Euprepis atlanticus, Scincidae, Erythrina velutina, Fabaceae, saurofilia, ilhas oceânicas. 


\section{Introduction}

Lizards are among the least expected vertebrate pollinators and we can hardly speak of saurophily - a syndrome that would encompass flower features suited to pollination by reptiles - or coevolved systems (but see Olsson et al. 2000). Nevertheless, there are several recent records of lizards that visit and supposedly or actually pollinate flowers, including species of Gekkonidae, Lacertidae, Polychrotidae, Scincidae, and Teiidae (e.g., Dearing 1993, Eifler 1995, Elvers 1977, Font \& Ferrer 1995, Pérez-Mellado \& Casas 1997, Perry \& Lazell 1997, Traveset \& Sáez 1997, Nyhagen et al. 2001, Olesen \& Valido 2003). Most if not all records of flowervisiting lizards are in islands, ranging in size from the Nitge islet in the Mediterranean (Pérez-Mellado \& Casas 1997) to Tasmania in the Pacific (Olsson et al. 2000). A recent review (Olesen \& Valido 2003) stresses that lizard pollination is an island phenomenon. Not surprisingly lizards seek nectar mostly on inflorescences - an arrangement well suited for a climbing visitor (see Westerkamp 1990 for a discussion on flowers visited by perching and hovering birds).

The Noronha skink Euprepis atlanticus (= Mabuya atlantica), a lizard endemic to Fernando de Noronha Archipelago in SW Atlantic (Mausfeld et al. 2002), attains up to $25 \mathrm{~cm}$ in total length, forages mostly on the ground and thrives on anything edible from human leftovers to its own eggs (Silva-Jr. et al. 2005). This 'little dragon' is even able to tear apart pieces from larger animals’ corpses (birds and fishes, IS pers. obs.). We report here on the Noronha skink's visits to flowers of the leguminous mulungu tree Erythrina velutina (Fabaceae) which blooms during the dry season. As the island has little or no natural freshwater supply during this period, we suggest that the skink takes the nectar both for its energetic sugars and the water content.

\section{Material and Methods}

Field observations were conducted at several sites from the sea level to about $50 \mathrm{~m}$ a.s.l. on the main island of Fernando de Noronha Archipelago (0350'S, 32¹5’W), off northeast Brazil (see Carleton \& Olson 1999 for map and description). The visits of the skinks to mulungu tree flowers were recorded and documented in October 2002 and 2004, and November 2003. We observed the lizards in a total of seven individual trees 3-18 m tall. During observational sessions of 20-50 min (totalling 11 h) we used 'focal animal' sampling in which all occurrences of specified actions were recorded (Altmann 1974). Besides written records, behaviour of the lizards on flowers was photographed and video-recorded, a voucher tape being on file at the Museu de História Natural, Universidade Estadual de Campinas (ZUEC tape \# 20). Three free-ranging skink individuals were caught, examined for pollen placement on their body, and released. Two individuals were maintained over a day in a wooden box along with two large, fresh inflorescences of the mulungu tree, to examine pollen placement on their body after visits to the flowers. We recorded flower biology features including time and period of anthesis (see Faegri \& van der Pijl 1980), receptivity of stigmas being tested with $\mathrm{H}_{2} \mathrm{O}_{2}$-catalase activity (Zeisler 1938). Nectar concentration and volume were taken in early morning from 22 flowers bagged in previous late afternoon, and measured with a portable refractometer and a microlitre syringe respectively.

\section{Results}

The Noronha skink (Euprepis atlanticus) climbed up to about $12 \mathrm{~m}$ to reach the flowers of the mulungu tree (Erythrina velutina), and visited the plants throughout the day. On reaching an inflorescence, the skink inserted its head into a flower and lapped the nectar accumulated at the flower's base. The exploitation of a given flower was done in 2-4 lapping bouts, each of them lasting 3-5 sec. Each open flower in an inflorescence was examined and probed for nectar. While seeking for nectar the Noronha skink crawled over the inflorescences and its body parts (head, back, belly, limbs) contacted the anthers and stigma (Fig. 1). Visits to each inflorescence lasted 40-201 sec (mean= 77.33, $\mathrm{SD} \pm 50.75, \mathrm{~N}=12$ ), this variation partly due to flower number (e.g., one skink stayed on an inflorescence with seven flowers for $155 \mathrm{sec}$ ). However, the skinks lingered on the inflorescences between the nectar-lapping bouts, and also on the branches between visits to different inflorescences (probably a thermoregulatory behaviour), which added to visitation period variation. The skinks moved from flower to flower on the same inflorescence, from one inflorescence to another, and between neighbour trees. One closely followed skink visited three small trees (height 2-3 m) in a row. Two to three skinks exploited the same tree at the same time (Fig. 2), the larger individuals chasing and/or dislodging the smaller ones from an inflorescence or a flower-bearing branch. Between nectar-drinking bouts, the skinks foraged on the ground for insects and other foods. After a day in the box along with the inflorescences, the two skinks had patches of pollen over their body (mostly on belly and chin), and there was pollen adhered on the flowers' stigmas.

The flowers were additionally visited by all three terrestrial bird species native to Fernando de Noronha Archipelago: the dove Zenaida auriculata noronha and two perching birds, the flycatcher Elaenia ridleyana and the vireo Vireo gracilirostris. In addition to flower visiting, we recorded the flycatcher foraging on the fruits of cultivated papaya trees.

The mulungu tree blooms from August to November (J. M. Silva-Jr. pers. comm.), the dry season at Fernando de Noronha Archipelago. The trees dwell at several sites of the archipelago and the yellowish orange colours of their blooming form tinged patches on the rocky habitat (Fig. 3). The inflorescences may bear up to 26 flowers, with 2-8 newly- 


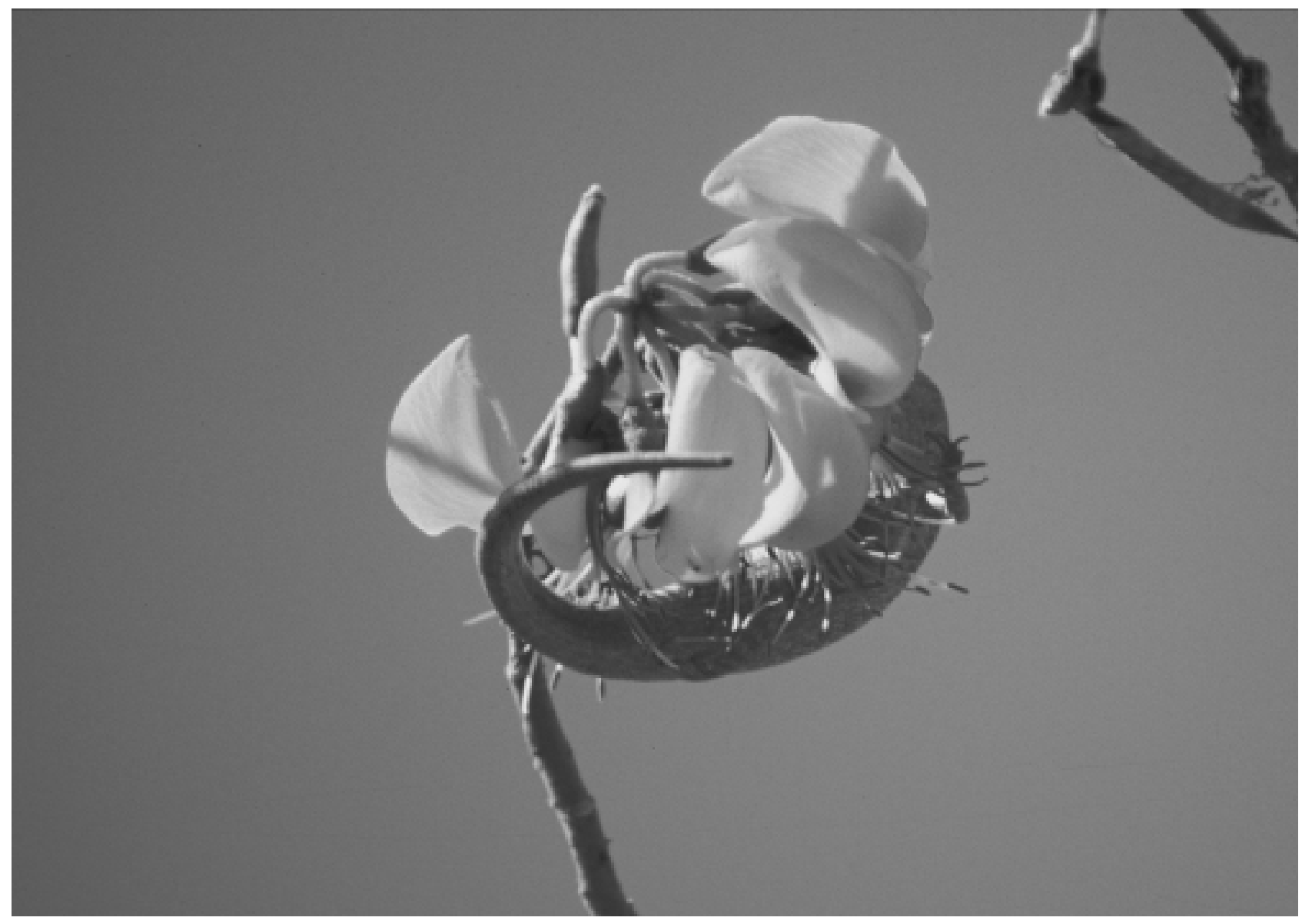

Fig. 1. A Noronha skink (Euprepis atlanticus) while exploiting an inflorescence of the mulungu tree (Erythrina velutina) at Fernando de Noronha Archipelago. 


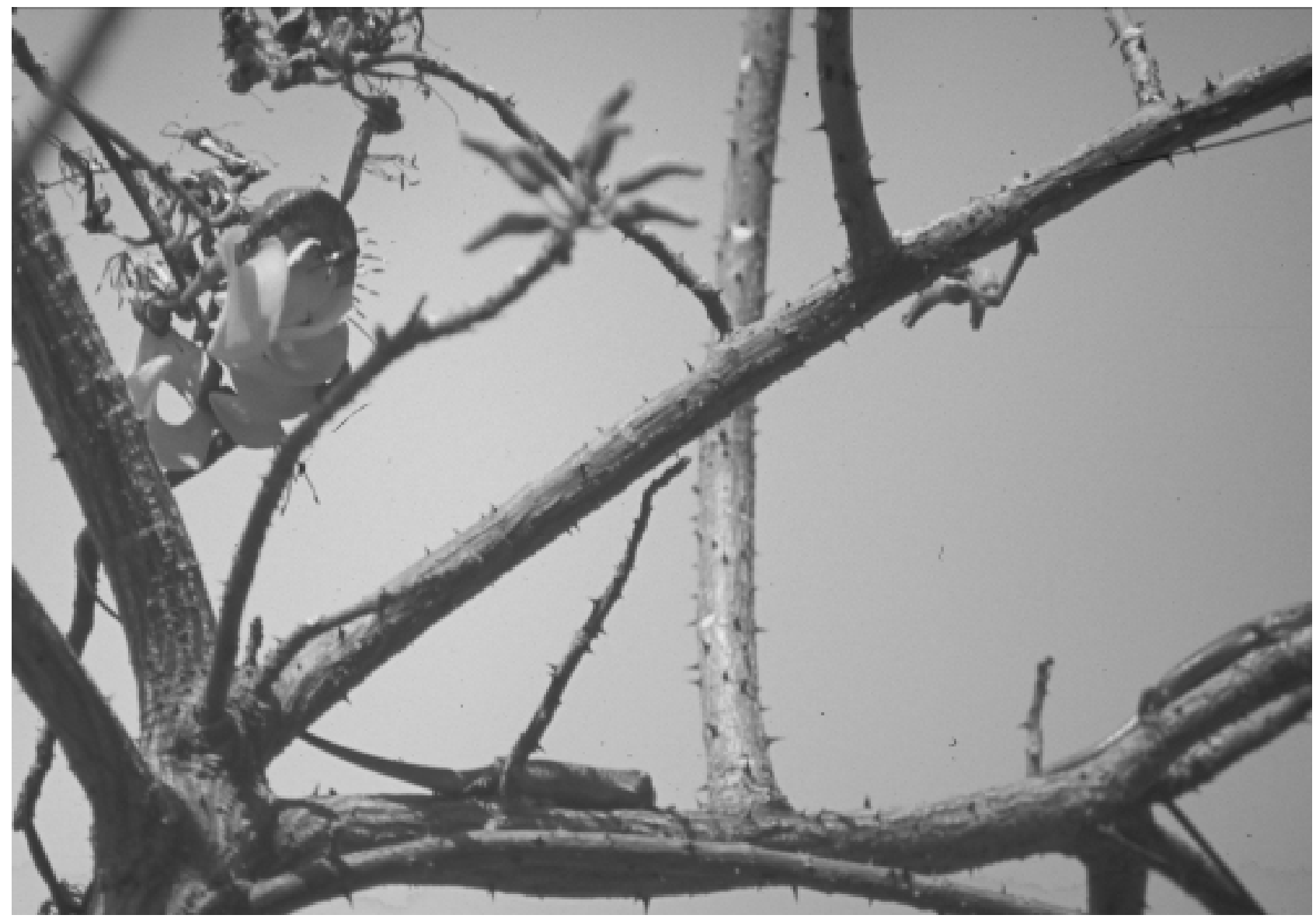

Fig. 2. Three Noronha skinks (Euprepis atlanticus) on the same mulungu tree (Erythrina velutina), the largest skink visiting the flowers (left) and the two lesser ones lingering on neighbour branches (below centre and right). 


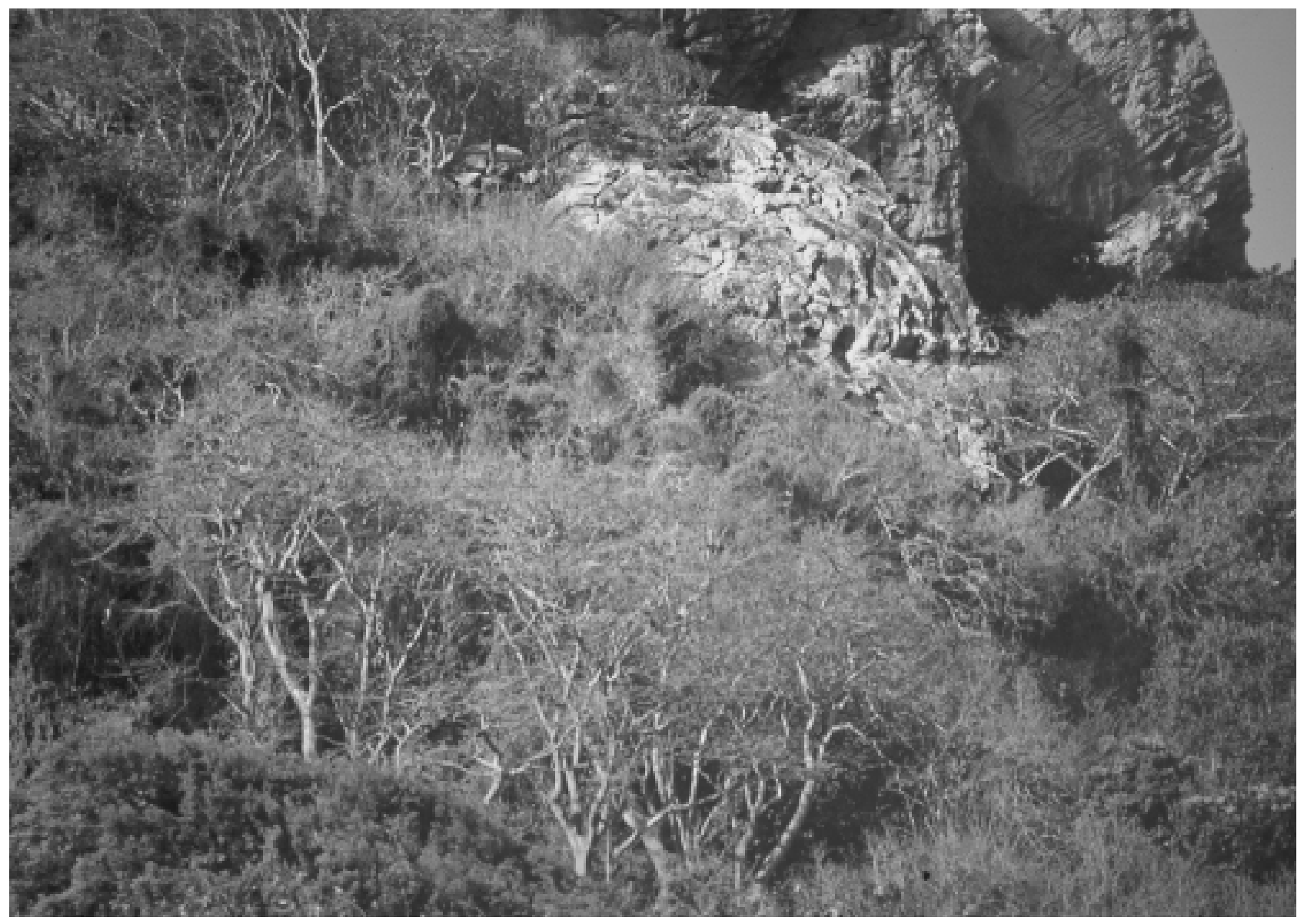

Fig. 3. A small group of blooming mulungu trees (Erythrina velutina) in the rocky landscape of Fernando de Noronha Archipelago. 


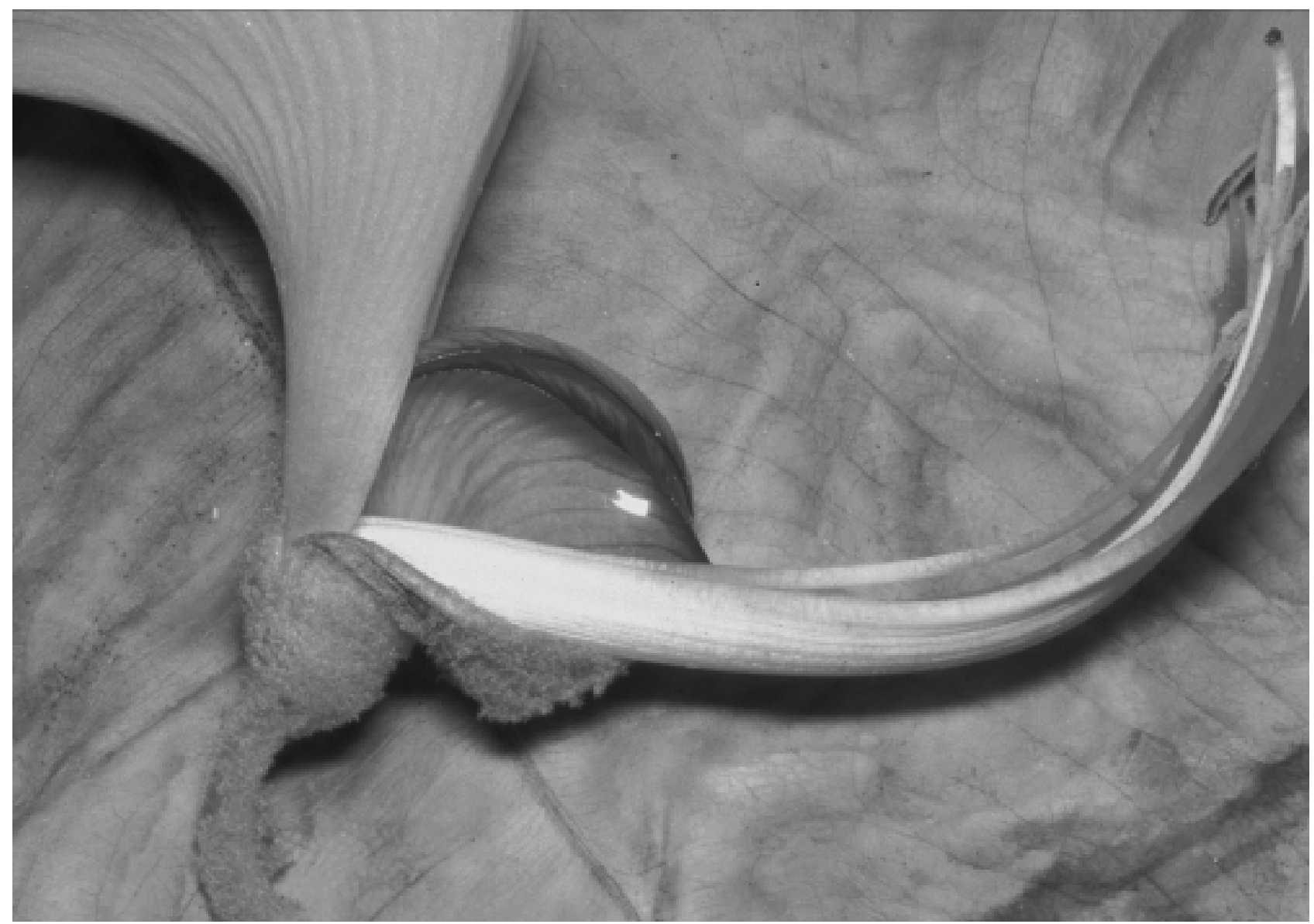

Fig. 4. A partly dismantled flower of the mulungu tree (Erythrina velutina) to show the large amount of nectar that accumulates at the corolla's base. 
open ones per day (mean=4.23, $\mathrm{SD} \pm 1.81, \mathrm{~N}=26$ ). Nectar is diluted (10.5-13\%), copious (Fig. 4), and available on flower opening. A single flower may accumulate up to $106 \mu \mathrm{l}$ of nectar in $55 \mathrm{~min}$. Each flower produces nectar continuously for one day, although its stigma remains receptive for two days. The yellow pollen (Fig. 4) adheres easily even to smooth and dry surfaces such as the Noronha skink scales.

\section{Discussion}

The nectar-seeking behaviour of the Noronha skink is similar to that recorded for other flower-visiting lizards, except for the skinks climbing on trees, not shrubs and herbs as recorded in most studies on nectar seeking lizards (e.g., Eifler 1995, Elvers 1977, Font \& Ferrer 1995, Perry \& Lazell 1997, Traveset \& Sáez 1997, but see Nyhagen et al. 2002 for Phelsuma geckos). Tree climbing for the Noronha skink would not be surprising, however, since several skink species are arboreal (Pianka \& Vitt 2003), and in spite of its predominantly ground-dwelling habits Euprepis atlanticus is a skilled climber (IS pers. obs.). Moreover, the little dragon of Noronha is a very versatile and opportunistic forager (Silva-Jr et al. 2005), and food resources on islands may be scarce for lizards (e.g., Pérez-Mellado \& Casas 1997, Olesen \& Valido 2003).

Although we did not examine closely the pollinating role (see Pérez-Mellado \& Casas 1997, Traveset \& Sáez 1997) of E. atlanticus, the pollen stuck on its scales throughout its wandering between the flowers and its bodily contact with the flowers' anthers and stigmas favours the view that the skink is a pollinating agent of Erythrina velutina. As the skinks visited neighbour trees, their activity likely favours cross-pollination and enhances the genetic variability (Webb \& Bawa 1983) of the mulungu tree.

Erythrina velutina produces nectar much less concentrated and in much larger amounts than two other species within the genus studied in Brazil. For E. speciosa the concentration is about $38 \%$ and the volume is about $15 \mu \mathrm{l}$ (Buzato et al. 2000), and for E. dominguezii these values are about 20\% and 65 $\mu$ l (Ragusa-Netto 2002). Blooming at the dry season is a trend for species of Erythrina in Brazil (Lorenzi 1992, Buzato et al. 2000, Ragusa-Netto 2002), but in the island habitat of Fernando de Noronha Archipelago, with little or no natural freshwater supply during drought, this trend seems much providential (see below). The importance of E. dominguezii nectar as food supply for birds during the fruit-short dry season was commented upon by Ragusa-Netto (2002).

Since the Noronha skink is not too much pressed by lack of food, as it is able to capitalize on almost anything edible (Silva-Jr et al. 2005, our pers. obs.), the diluted mulungu nectar may be regarded as a bonus in its daily feeding schedule. On islands, lizards tend to reach high population density and experience low predation risk, and thus may expand their diet to include nectar, pollen, and fruits (Olesen \& Valido 2003). At Fernando de Noronha Archipelago, Euprepis atlanticus has high population densities and is preyed on by introduced vertebrates only (SilvaJr. et al. 2005), which lends support to the above mentioned view (Olesen \& Valido 2003). An additional support to our assumption that the Noronha skink visits flowers for both sugars and water may be the fact that most if not all instances of flower-visiting and nectar-lapping lizards are recorded from oceanic islands (Olesen \& Valido 2003), mainly in relatively arid environments (e.g., Eifler 1995, Elvers 1977, Font \& Ferrer 1995, Pérez-Mellado \& Casas 1997, Perry \& Lazell 1997, Traveset \& Sáez 1997). The midsummer diet of the lacertid Podarcis lilfordi on Nitge islet is composed mostly of nectar (Pérez-Mellado \& Casas 1997), a further support to our view that versatile, insular lizards may be seeking flowers for water supply besides sugars.

Taken together, the Noronha skinks' day-round flower visitation, the mulungu trees blooming during the dry season, the large amount of diluted nectar, and the lack or scarcity of natural freshwater sources on the island, strongly indicate that the skinks seek nectar both for sugar and water intake. Even for lizards that dwell in xeric environments water intake is done by active drinking (Zug et al. 2001, Pianka \& Vitt 2003), and we may add dilute nectar intake for water balance as well (present paper). We strongly suspect that lizards' visits to flowers serve a dual purpose: energy acquisition (Olesen \& Valido 2003) and water balance, although this latter role of nectar in the physiology of flowervisiting lizards remains open to investigation.

\section{Acknowledgements.}

We thank J. M. Silva-Jr. (Centro Golfinho Rotador) for a constant and friendly helping hand; M.A. Silva (Ibama) for the warm reception and permission to study vertebrates at the Marine National Park of Fernando de Noronha; the FAEP-Unicamp, and FAPESP for essential financial support. The authors are recipients of scholarships from the CNPqBrasil. Two anonymous referees improved the paper.

\section{References}

ALTMANN, J. 1974. Observational study of behavior: sampling methods. Behaviour 49: 227-265.

BUZATO, S., SAZIMA, M. \& SAZIMA, I. 2000. Hummingbird-pollinated floras at three Atlantic forest sites. Biotropica 32: 824-841.

CARLETON, M. D. \& OLSON, S. L. 1999. Amerigo Vespucci and the rat of Fernando de Noronha: a new genus and species of Rodentia (Muridae: Sigmodontinae) from a volcanic island off Brazil's continental shelf. Am. Mus. Novit. 3256: 1-59. 
DEARING, M. D. 1993. An alimentary specialization for herbivory in the tropical whiptail lizard Cnemidophorus murinus. J. Herpetol. 27: 111-114.

EIFLER, D. A. 1995. Patterns of plant visitation by nectarfeeding lizards. Oecologia 101: 228-233.

ELVERS, I. 1977. Flower-visiting lizards on Madeira. Bot. Notiser 13: 231-234.

FAEGRI, K. \& van der PIJL, L. 1980. The principles of pollination ecology. Pergamon Press, Oxford.

FONT, E. \& FERRER, M. J. 1995. Gallotia galloti (Canary Islands lizard). Nectar feeding. Herp. Rev. 26: 35-36.

LORENZI, H. 1992. Árvores brasileiras: manual de identificação e cultivo de plantas arbóreas nativas do Brasil. Ed. Plantarum, Nova Odessa.

MAUSFELD, P., SCHMITZ, A., MISOF, B., VRCIBRADIC, D. \& ROCHA, C. D. 2002. Phylogenetic affinities of Mabuya atlantica Schmidt, 1945, endemic to the Atlantic Ocean Archipelago of Fernando de Noronha (Brazil): necessity of partitioning the genus Mabuya Fitzinger, 1826 (Scincidae: Lygosominae). Zool. Anz. 241: 281-293.

NYHAGEN, D.F., KRAGELUND, C., OLESEN, J. M. \& JONES, C. G. 2001. Insular interactions between lizards and flowers: flower visitation by an endemic Mauritian gecko. J. Trop. Ecol. 17: 755-761.

OLESEN, J. M. \& VALIDO, A. 2003. Lizards as pollinators and seed dispersers: an island phenomenon. Trends Ecol. Evol. 18: 177-181.

OLSSON, M., SHINE, R. \& BA’K-OLSSON, E. 2000. Lizards as a plant's 'hired help': letting pollinators in and seeds out. Biol. J. Linn. Soc. 71: 191-202.

PÉREZ-MELLADO, V. \& CASAS, J. L. 1997. Pollination by a lizard on a Mediterranean island. Copeia 1997: 593-595.

PERRY, G. \& LAZELL, J. 1997. Anolis stratulus (saddled anole). Nectivory. Herp. Rev. 28: 150-151.

PIANKA, E. R. \& VITT, L. J. 2003. Lizards: windows to the evolution of diversity. Univ. California Press, Berkeley.

RAGUSA-NETTO, J. 2002. Exploitation of Erythrina dominguezii Hassl. (Fabaceae) nectar by perching birds in a dry forest in Western Brazil. Braz. J. Biol. 62: 877-883.

SILVA-JR., J. M., PÉRES-JR., A. K. \& SAZIMA, I. 2005. Euprepis atlanticus (Noronha skink). Predation. Herp. Rev. 36: 62-63.

TRAVESET, A. \& SÁEZ, E. 1997. Pollination of Euphorbia dendroides by lizards and insects: spatio-temporal variation in patterns of flower visitation. Oecologia 111: 241248.

WEBB, C. J. \& BAWA, K. S. 1983. Pollen dispersal by hummingbirds and butterflies: a comparative study of two tropical plants. Evolution 37: 1258-1270.
WESTERKAMP, C. 1990. Bird-flowers: hovering versus perching exploitation. Bot. Acta 103: 366-371.

ZEISLER, M. 1938. Über die Abgrenzung der eigentlicher Narbenfläche mit Hilfe von Reaktionen. Beih. Bot. Zentralbl. 58: 308-318.

ZUG, G. R., VITT, L. J. \& CALDWELL, J. P. 2001. Herpetology: an introductory biology of amphibians and reptiles. $2^{\text {nd }}$ ed. Academic Press, San Diego.

Title: Little dragons prefer flowers to maidens: a lizard that laps nectar and pollinates trees

Authors: Ivan Sazima, Cristina Sazima, Marlies Sazima

Biota Neotropica, Vol. 5 ( number 1): 2005

http://www.biotaneotropica.org.br/v5n1/pt/ abstract?short-communication+BN00805012005

Recebido: 12/09/2004

Revisado: 12/11/2004

Publicado: 01/01/2005

ISSN 1676-0611 